\title{
The Impact of Place Attractiveness and Social Supports on Internal Return Migration
}

\author{
Thuy Thu NGUYEN ${ }^{1}$
}

Received: March 07, 2020 Revised: March 21, 2020 Accepted: April 10, 2020

\begin{abstract}
The paper explores the return migration choice of graduates, which takes place during the transition from higher education to the labor market. Graduate students, after a short time in temporary migration to cities for studying, have to make a decision of returning back home or staying in migration in urban areas for working. Drawing on the mechanism identified in the literature on internal migration, this empirical research tests the effects of two factors: place attractiveness and social supports factors on graduates' decision to return migration to hometown. A binary logit regression analysis was conducted with data from 502 surveyed graduates in Hanoi, Vietnam. The analysis of the motives reported by graduates indicates that return migration decisions cannot be reduced to a single dimension. Perceived attractiveness of a region such as quality of living environment, job opportunities, and social context of individuals positively impact on student' decision to return migration after graduation. The research results imply that, in a collectivistic country like Vietnam, students' choice of future career is strongly influenced by their social context, and choosing a place to work is not simply a matter of earning a higher salary or enjoying better working conditions, but is also related to family issues.
\end{abstract}

Keywords : Return Migration, Place Attractiveness, Family Support, Social Norm, Graduates

JEL Classification Code: J61, O15, R23

\section{Introduction}

In a growing knowledge economy nowadays, creativity and talent are becoming increasingly decisive in speeding up economic development and opportunity. Prosperity and growth of the city now depend more on the ability to attract knowledge workers and less on access to physical resources (Yigitcanlar, Baum, \& Horton, 2007). Rural communities continue to experience an undersupply of talent and highly educated labor, and efforts to attract young knowledge workers to rural areas have largely proved unsuccessful (Bjerke \& Mellander, 2016; Nguyen, Nguyen, Nguyen, \& Nguyen, 2020). Since then, a big question is how to attract

\footnotetext{
${ }^{1}$ First Author and Corresponding Author. Professor, Faculty of Business Management, The National Economics University, Vietnam [Postal Address: 207 Giai Phong Road, Dong Tam Ward, Hai Ba Trung District, Hanoi, 116000, Vietnam]

Email: thuyntqtkd@neu.edu.vn

(c) Copyright: The Author(s)

This is an Open Access article distributed under the terms of the Creative Commons Attribution Non-Commercial License (http://Creativecommons.org/licenses/by-nc/4.0/) which permits unrestricted noncommercial use, distribution, and reproduction in any medium, provided the original work is properly cited.
}

high skills and knowledge human resources, especially graduate students, for the development of the rural region. A greater knowledge about returning migrants and the locational choices of graduates would benefit many of these rural areas (Rérat, 2014). The reason why there is an interest in newly-graduated students stems from the fact they are young, highly skilled, highly motivated, and they are regarded as valuable human resources having knowledge and ready to be employed for the development of the economy and the society (Nguyen, 2015).

Migration literature has focused on various aspects of the migration process, including migration decision, settlement and return back to origin communities. While migration from rural to urban areas and international migrations has received wide interests, internal return migration has received less attention despite the fact that internal return migration to rural areas has important implications for communities and regions' development (Niedomysl \& Amcoff, 2010; Harrison, 2017).

A special research area of internal return migration education-based migration is understudied, particularly in the context of graduate students, who have to make work place decision after graduating from higher education 
(Chunyu, Liang, \& Wu, 2013). Young adults, who want to get higher education, temporarily migrate from their birthplace to the university city since higher education institutions are located mostly in urban places. The fact that a small proportion of students return back home to small city and rural regions after graduation, has been demonstrated in several studies (Crescenzi, Holman, \& Orru, 2017; Huang \& Zhang, 2013; Nguyen \& McPeak, 2010). However, although the pioneering works provide invaluable insights into graduates' return migration, there are still significant gaps in the literature. Scholars criticize the fact that the theoretical and empirical literature on return migration is too narrow and limited (Bjerke \& Mellander, 2016). Most studies of return migration are interested in the economic perspective, which explained the return decision by income differences in regions (Rérat, 2014).

Recently, the analysis of the motives reported by graduates indicates that internal migration motivations are complex and present a significant challenge for researchers (Crescenzi et al., 2017). The patterns of these young graduates' move in the city or return back rural hometown during the transition from universities to the labour market, need to be considered in a wide range of contexts (Buchenrieder, Dufhues, Möllers, Runschke, \& Sagyndykova, 2019). Migration decisions cannot be reduced to a single dimension (although income is important), are diverse, and depend on a variety of factors in which the social dimension is a significant factor (Chunyu et al., 2013; Buchenrieder et al., 2019). Furthermore, in developing countries, internal migration is increasing rapidly, and patterns of internal migration have been changing (Nguyen \& McPeak, 2010). Previous literature argued theoretically that return migrants tended to be the worst of the best, meaning that only those who failed would return. This argument is not totally true those days (Wang \& Fan, 2006; Junge, Diez, \& Schatzl, 2015; Harrison, 2017).

In developing countries, regional non-farm labour markets are developing and providing increasing employment opportunities in provincial and district capitals. The flow of migrants begins to move to home regions in order to find work since non-farm income opportunities in the rural emerged (Huang \& Zhang, 2013; Nguyen et al., 2020). Income issues have not been the only concern of graduates when making decision of returning or continuing migrate, they are now more concerned with the environment, quality of life, and social issues (Chunyu et al., 2013). However, empirical evidence taking into account these changing environment is missing.

Linking this discussion to the context of Vietnam a developing country, and taking a careful look at the theoretical frameworks identified in the literature on internal migration of graduates, I propose a conceptualize framework in which migration choice is determined by a combination of two aspects: place attractiveness (job opportunities, quality of life, and place attractiveness) and social factors (social norms and family supports). This research aims to provide empirical evidence on determinants of students' decision to return hometown. This study will, thus, contribute to the literature on return migration in several respects. First, this paper addresses return migration to rural hometown of graduates, who just finished their university education, taking a look at the combined influences of factors (social aspects and place attractiveness) and on career place choice. Second, taking the changing environment of Vietnam, a developing country, into consideration. The findings provide provincial policy makers valuable knowledge in attracting high quality human resources for rural economic development.

\section{Literature Review}

Return migration or circular migration is a concept capturing migrants who suspend their migration by returning to their places of origin (Dustmann \& Weiss, 2007). Return migrants obviously move back for many reasons. Lee (1966) categorizes the reasons for migration into two groups of factors. Factors can either be push factors, which are associated with the area of origin, or pull factors associated with attractiveness of the area of destination. Following individualistic approach, these factors depend on personal perception of a city. Pull factors like conditions one hopes or thinks to find in the area of destination, potential for employment, place facilities, quality of life, etc. Besides that, based on the ecological systems theory of Bronfenbrenner (1994), I believe that the career choice of a person and the individual migration decision is not only impacted by the attractiveness of the destination, but also motivated by a number of social factors. Those factors contribute to the attractiveness of a place to entice graduates to return home (Constant \& Massey, 2002).

\subsection{Place Attractiveness and Return Migration Decision}

Place attractiveness (considered also as territorial attractiveness, regional attractiveness or city attractiveness) is conceptualized as something positive or as something that exerts a physical or emotional pulling power in a place (Hidalgo \& Hernandez, 2001). The ability of places to attract migrants are qualities of destination regions, which is a fundamental issue in migration research (Bjerke \& Mellander, 2016). Places' ability to attract the right kind of workforce to enhance the competitiveness of trade, service and industry has frequently been emphasized in return migration studies (Williams \& Vaske, 2003). Yigitcanlar et al. (2007) propose place attractiveness from a migration perspective, develop place attractiveness on the basis of a subjectively defined attractiveness based on stated preferences. The attractiveness 
of places in migrants' point of view involves three main aspects: (1) job opportunities in place, (2) place attachment, and (3) quality of life.

\subsubsection{Job Opportunities and Return Migration Decision}

Previous researches by Soon (2010), Rérat (2014), and Pearson and Andres (2010) point out that students who have good perceptions of the working environment of rural home have a higher probability to return. Better chances for getting a good job have substantial impact on immigration and outmigration (Huang \& Zhang, 2013). Favourable perceptions of chances for higher wage at home, perceptions of skill use opportunities and job promotion prospects at home encourage students to return (Buchenrieder et al., 2019). The returnees do not have the obligation to return, but choose to do so since they see increasing opportunities for them in their home communities or feel that they can move up faster in their career development in their home communities. Good perceptions of job finding opportunities in hometown also have a large and significant impact on a student's return intention and decision (Soon, 2010; Rérat, 2014; Crescenzi et al., 2017; Buchenrieder et al., 2019). Thus,

Hypothesis 1: Job opportunities in hometown is positively related to return migration decision.

\subsubsection{Quality of Living Environment and Return Mi- gration Decision}

Quality of living environment refers to "the set of characteristics that define a place, making it attractive and live able" (Ezmale, 2012). Quality of living environment is the "live ability" of a region, commonly expressed in indicators including the standard and variety of education and community facilities, crime level, climates, amenities, environmental quality, housing affordability, and transportation access (D'agostini \& Luiz, 2008). Quality of living environment can be influenced by local government to achieve a clean environment, free access to water for citizens, and a friendly climate (Güngör \& Tansel, 2008).

Traditionally, in several studies on relocation of households between central areas and suburbs, the role of living environment is highlighted (Rérat, 2014). In research on amenity-led or lifestyle migration in small rural communities, the importance of the quality of life and residential facilities in migration has again been strongly indicated (Buchenrieder et al., 2019). If a city can offer a wide range of natural amenities and various outdoor recreation facilities, it can attract knowledge workers (Lalli, 1992). Attracting and retaining population to rural areas can be a challenge as most people prefer to settle in larger cities for higher income and job opportunities. However, rural communities can attract and retain population by promoting the benefits of living and working in smaller communities such as lower living expenses, safe neighbourhoods, clean atmosphere and a strong network of friends, family, and ethnic group (Pearson \& Andres, 2010). Research on return intention of students confirm that a good perception of the living environment in the hometown relates to intention to return (Bjarnasona \& Thorlindssonb, 2006; Pearson \& Andres, 2010).

Hypothesis 2: Quality of living environment is positively related to return migration decision.

\subsubsection{Place Attachment and Return Migration Decision}

Place attachment is a positive, affective bond or association between individuals and their residential environment (Hidalgo \& Hernandez, 2001). Place attachment describes a special feeling toward certain places. As such, place attachment increases feelings of belonging to one's community and is an important component of peopleplace relation (McAndrew, 1998). Place attachment can be expressed by personal sentiments by having deep affection for, and being proud of, the place of origin, by a desire to contribute to a place (Jorgensen \& Stedman, 2001). Rural provinces can have advantages over big cities in attracting labour motivated by proud and love of their citizens. Individuals usually develop very strong sentimental and emotional attachments to the places where they live, that create feelings of comfort and security (Williams \& Vaske, 2003). Lalli (1992) has noted that it is important to take the strong emotional attachments between people and place into account when attempting to understand the variety of human experiences. Place attachment makes people become dependent upon regions or on a certain kind of environment. An individual with a strong place attachment can be only satisfied with another location as long as those places have similar characteristics. Feeling of place attachment makes people homesick when moving to involuntary relocation (as in case of going to city for higher education) and grows the desire to restore the past experiences of being at home or return to the original place (Hidalgo \& Hernandez, 2001).

Researchers studying return migration have specifically recognized the importance of place ties and place attachment, or the bonding of people to places. Bjarnasona and Thorlindssonb (2006) indicate that relationship of a person with his hometown because of close friends, regular social contact with the hometown, good impression with the hometown, etc., are factors that push them to return home. The traditional view regards return migration as a failure. Internal return migrants are usually seen as losers in the competitive labour market at the destinations and have to return due to their lower level of education and skills. A sense of attachment to the local area can help people get over 
the traditional feeling of losing out. Hometown love and the felling to be included or valued by the local community are important factor in the return decision making process (Harrison, 2017).

Hypothesis 3: Place attachment is positively related to return migration decision.

\subsection{Social Dimensions and Return Migration Decision}

Vietnam is a collectivistic country; individual decision still heavily relies on social reference group. Scholars emphasize the importance of social variables relate to the career interests of Asians - in collectivism country (Wang \& Fan, 2006; Mustapa, Noor, \& Mutalib, 2018). Therefore, I propose that social factors combined with place attractiveness influence on return decision.

\subsubsection{Social Norms and Return Migration Decision}

Social norms or the subject's perception of other people's opinion of the proposed behaviour was examined (Ajzen, 1991). Yue, Li, Feldman, and Du (2010), Huang and Zang (2013) have indicated that greater family encouragement to students to settle in big city results in a greater tendency to discourage returning. Junge et al. (2015) find that parental expectations and social prestige of career choice are highly correlated with career decision of South Asians. Social encouragement in traditional Asian people have more influence on return migration. The research by Buchenrieder et al. (2019) indicates that, if friends are supportive and parents have high expectations for the return, graduates are willing to return home for working. Because social ties in the Vietnamese society remain very strong, there are good reasons to expect that concerns about the social opinions of returning may affect students' return decisions. Family members, friends, reference group's norms can impact individual decision.

Hypothesis 4: Social norms is positively related to student's return migration decision

\subsubsection{Family Support and Return Migration Decision}

Family support includes emotional, practical, spiritual, informational and financial supports from family as a resource for migrant (Merry, Hanley, Casares, Archambau, $\&$ Mogere, 2019). The existing studies suggest that family support is not only primarily in the form of emotional support, like family members' encouragement to return home, but also in the form of providing practical help as well, like family' preparation of facilities for settling in the hometown if graduates come back home to work, helping migrant to access resources, caring for their children, receiving parenting advice on a range of topics (social, nutrition and discipline), and assistance to resolve family conflicts. (Merry et al., 2019; Mustapa et al., 2018).

Family influence on return migration has been mentioned in the literature regarding different aspects. Family influence is an important force in preparing students for their role as workers (Nota, Ferrari, Solberg, \& Soresi, 2007). Young people form their attitude about work and career as a result of interaction with the family. Crescenzi et al. (2017) suggests that the redirection from larger to smaller cities may be feasible if wage incentives are supplemented by advance information and assistance in moving from family and communities. Gungo and Tansel (2008) confirm that family support is an important determinant of students' return intention, greater family support for settling at home results in greater probability of returning. Career-related choices are likely to be a family choice since children are expected to stay with and take care of their parents in old age. (Bjarnasona \& Thorlindssonb, 2006) have mentioned in their research the emotional support family members provide for the return migration. The factors encouraging young people to stay in rural areas include family and social preparation to stay or lack of necessary resources to move. When the respondent's family is not supportive of the decision to find a job in big city, the probability of return intentions is higher. The attachments to family members in the place of origin lower the costs of returning home, both psychological and monetary, and raise the costs of remaining in urban society (Yue et al., 2010; Constant \& Massey, 2002).

The family is considered a central place in Eastern society like Vietnam; any Vietnamese can expect to require some form of family supports, but at the same time be subject to moral obligations towards their family (Nguyen, 2015). In addition, family's members also pass on values and beliefs about career and life goals, and their expectations may influence their children's career-related decisions (Merchant, Kumar, \& Mallik, 2017). Choosing a place to work and settle right after graduation is an important decision in the early stage of career development of individuals. At that time the decision influenced by family supports.

Hypothesis 5: Family support is positively related to return migration decision.

\section{Research Methodology}

This quantitative research is testing hypotheses and a model of determinants of university graduates' decision to return migrate hometown for work. The research questionnaire was designed using measures from previous research with adaptation for the Vietnamese context. Place attachment was measured using five items adapted from Jorgensen and Stedman (2001); quality of living environment with six items from Ezmale (2012); family support with five 
items from Boyar, Campbell, Mosley, and Carson (2014); job opportunities with three items from Soon (2010); and social norms with three items from Ajzen (1991). All measures use 5-point Likert scale, from 1 (strongly disagree) to 5 (strongly agree).

We pretested the questionnaire through interviews in qualitative study and made necessary changes for the purpose of accuracy and understanding before the final revision and administration in the study. We focused on a sample of graduates with rural place of origin, who graduated within two years from the schools. We collected data by uploading soft electronic copies of survey the questionnaire online via Google docs. The questionnaires were sent to 1902 email addresses obtained from alumni of five universities in Hanoi. We received 510 answers (response rate of 26,8\%). After screening the questionnaires, we eliminated responses due to missing important information or inconsistency or bias answers. The final sample size totals 502 responses.

Statistical analysis was carried out using SPSS 22.0 software. First, exploratory factor analysis (EFA) and Cronbach's Alpha are implemented to assess the validity and reliability of variables. Second, the binary logit regression was applied to test the proposed relationships.

\section{Results and Discussion}

\subsection{Results}

A total 502 questionnaires have been used for analysis; $(57,2 \%)$ are men. The respondents' place of birth: $76,6 \%$ are from rural areas and 23,4\% from other cities; $95 \%$ of the respondents have parents still living in their hometown; $69,2 \%$ of the respondents stay in Hanoi for working after graduation; $20,5 \%$ return to hometown and $10,3 \%$ return to other cities for working.

All the measures in this research have been assessed for validity and reliability by using Cronbach's Alpha and EFA analysis. First, EFA analysis has been done at the same time for all five independent variables with Varimax rotation method. Items QL1 of the "quality of living environment" and FS5 of the "family support" measures have been eliminated due to their wrong loading and under-qualified Cronbach's Alpha. After the elimination of those variables, EFA has been conducted again; the result supports the validity of the measurement instruments, and the variables were then loading on the factors appropriate to the variables. Table 1 provides an overview of the rotated component matrix; all items below 0.3 were cut off to better visualize which components the variables are loading on. The factor loadings, the correlation between the factor and the variables, are lowest 0.575 and highest 0,859 , which indicates a high correlation. The total variance explained by these four factors is $69,1 \%$. Eigenvalue $>1$; $\mathrm{KMO}-$ Meyer $=0.851(>0.6)$. In summary, the analysis provided evidence to support the validity of the measurement instrument.

Then, Cronbach's Alpha analysis for dependent variables shows that all variables are at minimum 0.80 . All variables are assumed to be internally consistent and are reliable (see Table 2).

We tested the relationship between factors with dependent factor - decision to return migration to hometown - by using binary logistic regression analysis since the research dependent factor is a categorical (dichotomous) variable (coded: 1 (return hometown) and 0 (stay in Hanoi or move to other places). In the first binary logistic regression model (control model), the dependent variable is decision to return migration to hometown with three control variables, the model is significant (Nagelkerke R Square $=0.07$, -2 Log likelihood $=520519, \mathrm{p}<.00)$. All control variables: place of birth, gender and parents still living in hometown, do not

Table 1: Rotated Component Matrix

\begin{tabular}{|l|c|c|c|c|c|}
\hline \multicolumn{5}{|c|}{} & \multicolumn{5}{|c|}{ Component } \\
\cline { 2 - 6 } & $\mathbf{1}$ & $\mathbf{2}$ & $\mathbf{3}$ & $\mathbf{4}$ & $\mathbf{5}$ \\
\hline QL6 & .841 & & & & \\
\hline QL5 & .811 & & & & \\
\hline QL1 & .718 & & & & \\
\hline QL3 & .687 & & & & \\
\hline QL4 & .656 & & & & \\
\hline QL2 & .573 & & & & \\
\hline PA2 & & .822 & & & \\
\hline PA 1 & & .808 & & & \\
\hline PA 3 & & .763 & & & \\
\hline PA 5 & & .690 & & & \\
\hline PA 4 & & .575 & & & \\
\hline FS2 & & & .859 & & \\
\hline FS4 & & & .843 & & \\
\hline FS3 & & & .804 & & \\
\hline FS1 & & & .772 & & \\
\hline JO2 & & & & & \\
\hline JO1 & & & & & \\
\hline JO3 & & & & & \\
\hline SN1 & & & & & \\
\hline SN3 & & & & & \\
\hline SN2 & & & & & \\
\hline Extraction Method: Principal Component Analysis. & \\
\hline Rotation Method: Varimax with Kaiser Normalization. & \\
\hline a. Rotation converged in 6 iterations. & & \\
\hline
\end{tabular}

(Source: author'research) 
have significant and positive relation with the decision to return migration for working in hometown.

The second model with the dependent variable is decision to return migration for working in hometown with five independent variables and three control variables. The model is significant (Nagelkerke R Square $=0.566$, -2 Log likelihood $=293.799$, Cox \& Snell R Square $=.366, \mathrm{p}<$ .001). $2 / 3$ control variables (gender and place of birth) have not got a significant relationship with decision to return working in hometown. Parents in hometown have positive and significant relationship with decision to return migration for working in hometown. Only 4/5 independent variables tested have significant and positive relations with decision to return migration for working in hometown. In descending

Table 2: Variable measurement

\begin{tabular}{|c|c|c|c|}
\hline Variables & $\begin{array}{l}\text { No of } \\
\text { items }\end{array}$ & Research & $\begin{array}{c}\text { Cronbach's } \\
\text { alpha }\end{array}$ \\
\hline $\begin{array}{l}\text { Place } \\
\text { attachment } \\
\text { (PA) }\end{array}$ & 5 & $\begin{array}{c}\text { Jorgensen \& } \\
\text { Stedman (2001) }\end{array}$ & 0.870 \\
\hline $\begin{array}{l}\text { Quality of living } \\
\text { (QL) }\end{array}$ & 6 & Ezmale (2012) & 0.861 \\
\hline $\begin{array}{l}\text { Family support } \\
\text { (FS) }\end{array}$ & 5 & $\begin{array}{c}\text { (Boyar, } \\
\text { Campbell, } \\
\text { Mosley, \& } \\
\text { Carson, 2014) }\end{array}$ & 0.871 \\
\hline $\begin{array}{l}\text { Job } \\
\text { opportunities } \\
\text { (JO) }\end{array}$ & 3 & Soon (2010) & 0.854 \\
\hline $\begin{array}{l}\text { Social norms } \\
\text { (SN) }\end{array}$ & 3 & Ajzen, (1991) & 0.804 \\
\hline
\end{tabular}

(Source: author' research) order, they are: (1) Job opportunities (standardized $\beta=$ 1.476, $\mathrm{p}<0.01$ ); (2) Perceived quality of living environment in hometown (standardized $\beta=.867, \mathrm{p}<0.01$ ); (3) Family support (Standardized $\beta=.737, \mathrm{p}<0.01$; and (4) Social norms (standardized $\beta=.630, \mathrm{p}<0.05$ ). Place attachment does not significantly relate with decision to return working in hometown $(\mathrm{P}>.1)$ (see Table 3).

Hypothesis H1, H3, H4, and H5 are supported by the research data. However, hypothesis $\mathrm{H} 2$ is not supported.

Table 4 shows that this model allows to correctly classify $381 / 394(96,7 \%)$ of the subject's occurrences; deciding to stay in urban are correctly predicted. We also see that this rule allows to correctly classify $67 / 108=62 \%$ of the subjects deciding to return migration to hometown. Overall our predictions were correct 448 out of 502 observes, for an overall success rate of $89,2 \%$.

\subsection{Discussion}

This paper addresses the return migration of graduates in Vietnam - a developing country. A majority of them do not return to their place of origin after graduation $(79,5$ $\%$ ). $69,2 \%$ of the respondents stays in migration in urban regions for work after graduation. These results point to the attraction of urban regions and it is in accordance with many studies (Junge et al., 2015; Nguyen \& McPeak, 2010), which highlight the migration trend from rural to urban regions in developing countries. The reason for the low return rate to rural areas comes from the fact that there is inequality between rural-urban incomes in Vietnam over the past years, which is recognised in Nguyen et al. (2020). In general, compare to internal migrants in other countries, return migration pattern in Vietnam exhibits both similar and dissimilar patterns from previous research. The perception of different aspects of home country, particularly the aspect of

Table 3: Binary Logistic Regression Model: Variable in the equation

\begin{tabular}{|c|c|c|c|c|c|c|c|}
\hline \multirow{2}{*}{ Step $1^{a}$} & \multirow{2}{*}{ Gender } & \multirow{2}{*}{$\begin{array}{c}\mathbf{B} \\
100\end{array}$} & \multirow{2}{*}{$\begin{array}{l}\text { S.E. } \\
.273\end{array}$} & \multirow{2}{*}{$\begin{array}{c}\text { Wald } \\
.133\end{array}$} & \multirow{2}{*}{$\begin{array}{c}\mathbf{d f} \\
1\end{array}$} & \multirow{2}{*}{$\begin{array}{l}\text { Sig. } \\
.715\end{array}$} & \multirow{2}{*}{$\begin{array}{c}\operatorname{Exp}(\mathbf{B}) \\
1.105\end{array}$} \\
\hline & & & & & & & \\
\hline & $\begin{array}{l}\text { Parents still live in } \\
\text { hometown }\end{array}$ & 1.969 & .872 & 5.099 & 1 & .024 & 7.160 \\
\hline & Place of birth & .292 & .258 & 1.279 & 1 & .258 & 1.339 \\
\hline & Social norms & .630 & .184 & 11.741 & 1 & .001 & 1.878 \\
\hline & Place attachment & .182 & .258 & .498 & 1 & .480 & 1.200 \\
\hline & Family support & .737 & .171 & 18.486 & 1 & .000 & 2.089 \\
\hline & $\begin{array}{l}\text { Job opportunities in } \\
\text { hometown }\end{array}$ & 1.476 & .228 & 41.790 & 1 & .000 & 4.374 \\
\hline & $\begin{array}{l}\text { Quality of living in } \\
\text { hometown }\end{array}$ & .867 & .223 & 15.166 & 1 & .000 & 2.379 \\
\hline & Constant & -14.430 & 1.513 & 90.914 & 1 & .000 & .000 \\
\hline
\end{tabular}

(Source: author' research) 
Table 4: Binary Logistic Classification Table

\begin{tabular}{|c|c|c|c|c|c|}
\hline \multirow{3}{*}{$\begin{array}{l}\text { Step } \\
1\end{array}$} & \multirow[t]{3}{*}{ Observed } & & \multicolumn{3}{|c|}{ Predicted } \\
\hline & & \multicolumn{2}{|c|}{ Decision } & \multirow{2}{*}{$\begin{array}{c}\text { Percentage } \\
\text { Correct }\end{array}$} & \\
\hline & & .00 & 1.00 & & \\
\hline & \multirow[t]{2}{*}{ Decision } & .00 & 381 & 13 & 96.7 \\
\hline & & 1.00 & 41 & 67 & 62.0 \\
\hline & \multicolumn{2}{|c|}{$\begin{array}{c}\text { Overall } \\
\text { Percentage }\end{array}$} & & & 89.2 \\
\hline \multicolumn{6}{|c|}{ a. The cut value is .500} \\
\hline
\end{tabular}

(Source: author' research)

job opportunities, is generally found to have larger impacts on return decision than demographic and socio-related factors. Job opportunities offered in one' rural hometown positively affect the returning decision and is the strongest factor influencing the return migration decision. This is consistent with Rérat (2014), Soon (2010), Crescenzi et al., (2017) and Buchenrieder et al., (2019). Graduates are also more attracted to places offering quality living conditions like prosper public services, good educational facilities, shopping services and better quality of infrastructure. This confirms the arguments that quality of amenities are relevant when choosing career location (Niedomysl \& Amcoff, 2010). Graduates do not have to return, but choose to do so since they see increasing job-related opportunities, and they feel that they can live well with the development of their home countries.

The impact of family support is also important. The results of the study indicate that family support strongly and positively affect the graduate's decision to return to their hometown to work. This result supports the argument of Güngör and Tansel (2008) and Crescenzi et al. (2017) that, if the graduate's family support is strong, it is possible that returning to their hometown to work will be strong as well. The returning students expect members of their family to support them in finding a job, buying house or starting a business. In general, a person has supports from his parents, relatives, or the community, and the area where he or she used to live, which is consistent with the finding of Nguyen (2015) and Merchant et al (2017). Family influences graduates' migration decisions in combination with the place attractiveness.

Social norms factor is an important criteria in the graduates' decision to return to their home region. Family members, friends, and reference group expectation are strong factors to impact the returning decision to work in one's hometown. This result is consistent with an argument of Wang and Fan (2006) and Huang and Zang (2013) who propose that whether migration happens or not will depend on the view of relating people, family and community in a collectivistic country, where individual decision still heavily relies on social reference group (Jung, 2019). Having their parents living in the region increases the chance of returning to that area, as have social ties there. This is consistent with research from Rérat (2014) and Bjerke and Mellander (2016).

Contrary to migrants in other countries, Vietnamese people were much less sensitive to place attachment when deciding their return migration. Place attachment in this sample group is quite high (mean $=3,885$ ), expressing the love of the hometown of Vietnamese people. However, the results of this study indicate that place attractiveness does not significantly affect the returning decision. This result contrasts with research results in other countries (Bjarnasona $\&$ Thorlindssonb, 2006; Harrison, 2017). In previous studies, personal place attachment can stimulate in- migration and discourage out-migration decision. This mechanism does not occur in this case; place attachment with their hometown does not relate to decision to return. One possible reason is that a large Western literature has examined the role of place attachment in international return migration context where the returnee has been seen as a loser. A sense of attachment to the local area can help people get over the traditional feelings of failure. This research focuses on inter-provincial migrants in the Vietnamese context, changing the mind-set that the returnee is not a loser; place attachment may not be an issue to be considered. Whether internal migration in Vietnam really is the exception would require a larger and more representative study in the future.

The findings of this research provide empirical evidence to confirm the Theory of Migration and ecological systems theory. The career choice of a person and the individual migration decision is not only impacted by attractiveness of destination, but also motivated by a number of social factors that contribute to the attractiveness of a place to push graduates to return hometown.

The research has several limitations. First, it relied on the self-reported subjective measures of graduates. The cross-sectional study design was limited to determining the long-term impact and causal associations between the study factors and decision to return to work. Longitudinal study with appropriate time-series data on return migration and other variables may prove particularly useful in analysing the determinants and consequence of migration because they permit a distinctly different approach to the problem of sample selection (i.e., longitudinal data permit researchers to control more directly for unobserved variables that are correlated with the migration decision). Future research should implement a longitudinal study with appropriate time-series data on return migration. Students could be surveyed twice at one-year, five-years, and 10-years out of college. It would be better to incorporate the qualitative perspective for the future analysis, or to employ a sequential explanatory mixed-method research design that involving both quantitative and qualitative methods. This could help 
researchers gain an in-depth understanding of the factors that determine college graduates' work migration decision with more comprehensive evidence to generate effective policies about work migration.

\section{Conclusion}

This paper analyses the reasons why graduates return back to their rural home region after university. The analysis of the motives reported by graduates indicates that migration decisions cannot be reduced to a single dimension, but a combination of several factors. This paper has two major contributions to the internal return migration literature. First, it provides empirical evidence about the positive impact of perceived attractiveness of a region such as quality of living environment and job opportunities to student' decision to return migration after graduation. Place attachment is not significantly correlated to return decision in this study. Second, the research results confirmed the fact that, in collectivistic country such as Vietnam, students' choice of future career is strongly influenced by their social context. Social norms and family support, not surprisingly have considerable weight in the return migration decisions of the surveyed respondents. The results imply that choosing a place to work is not simply a matter of earning a higher salary or enjoying better work conditions, but is also familyrelated in Eastern individuals.

\section{References}

Ajzen, I. (1991). The theory of planned behavior. Organizational Behavior and Human Decision Processes, 50(2), 179-211.

Bjarnasona, T., \& Thorlindssonb, T. (2006). Should I Stay or Should I Go? Migration Expectations among Youth in Icelandic Fishing and Farming Communities. Journal of Rural Studies, 22(3), 290-300. https://doi.org/10.1016/j.jrurstud.2005.09.004.

Bjerke, L., \& Mellander, C. (2016). Moving home again? Never! The locational choices of graduates in Sweden. The Annals of Regional Science. Springer, 59(3), 707-729. DOI: 10.1007/ s00168-016-0777-2.

Boyar, L. S., Campbell, N. C., Mosley, J. C., \& Carson, M. C. (2014). Development of a work/family social support measure. Journal of Managerial Psychology, 29(7), 901-920. https://doi. org/10.1108/JMP-06-2012-0189.

Buchenrieder, G., Dufhues, T., Möllers, J., Runschke, D., \& Sagyndykova, G. (2019). Return to the countryside: The return intentions of highly educated young people in the Akmola province of northern Kazakhstan. Population, Space and Place, 26(2), 1-14. doi:10.1002/psp.2273

Chunyu, M., Liang, Y., \& Wu, Z. (2013). Interprovincial Return Migration in China: Individual and Contextual Determinants in Sichuan Province in the 1990S. Environment and Planning A, 45(12), 2939-2958. doi:10.1068/a45360.
Constant, A., \& Massey, D. (2002). Return migration by German guest workers: Neoclassical versus new economic theories. International Migration, 40(4), 5-36. https://doi. org/10.1111/1468-2435.00204.

Crescenzi, R., Holman, N., \& Orru, E. (2017). Why do they return? Beyond the economic drivers of graduate return migration. The Annals of Regional Science, Springer, 59(3), 603-627. https:// doi.org/10.1007/s00168-016-0762-9.

D'agostini, \& Luiz, R. (2008). Quality of Life and Quality of Living Conditions in Rural Areas: Distinctively Perceived and Quantitatively Distinguished. Social Indicators Research, 487499.

Dustmann, C., \& Weiss, D. (2007). Return Migration: Theory and Empirical Evidence from the UK. British Journal of Industrial Relations, 236-256.

Ezmale, S. (2012). Startegies for enhancing attractiveness of the cities in Latgale region'. European integration studies, 6, 121127, DOI: 10.5755/j01.eis.0.6.1601.

Güngör, N., \& Tansel, A. (2008). Brain drain from Turkey: an investigation of students' return intentions. Applied Economics, 40(23), 3069-3087. doi:10.1080/00036840600993999.

Harrison, J. A. (2017). Rust Belt Boomerang: The Pull of Place in Moving Back to a Legacy City. City \& Community, 16(3), 263-283. doi:10.1111/cico.12245.

Hidalgo, M., \& Hernandez, B. (2001). Place attachment: conceptual and empirical questions. Journal of Environmental Psychology, 21, 273-281. doi:10.1006/jevp.2001.0221.

Huang, Q., \& Zhang, G. (2013). The Intention of Resettling in Cities (towns) of China's New-generation of Migrant Workers and Individual-level Determinants. Paper presented at the 2nd International Conference on Science and Social Research. doi:10.2991/icssr-13.2013.125

Jorgensen, B., \& Stedman, R. (2001). Sense of place as an attitude: lakeshore owners attitudes toward their properties. Journal of Environmental Psychology, 21, 233-248.

Junge, V., Diez, J., \& Schatzl, L. (2015). Determinants and Consequences of Internal Return Migration in Thailand and Vietnam. World Development, 71, 94-106,.

Jung, M. H. (2019). The Effect of Social Capital on Personal Happiness: A Focus on Service Inderstry Employees. Journal of Asian Finance, Economics and Business, 7(1), 291-299. https://doi.org/10.13106/jafeb.2020.vol7.no1.291

Lalli, M. (1992). Urban-related identity: theory, measurement, and empirical findings. Journal of Environmental Psychology, 12, 285-305.

Lee, E. S. (1966). A Theory of Migration. Demography, 3(1), 4757.

McAndrew, F. T. (1998). The measurement of "rootedness' and the prediction of attachment to hometown in collegde students. Journal of Environmental Psychology, 18(4), 409-417.

Merry, L., Hanley, J., Casares, M., Archambau, I., \& Mogere, D. (2019). Migrant families with children in Montreal, 
Canada and transnational family support: a protocol for a focused ethnography. BMJ open, http://dx.doi.org/10.1136/ bmjopen-2019-02907.

Merchant, P., Kumar, A., \& Mallik, D. (2017). The Role of Quality of Relations in Succession Planning of Family Businesses in India. Journal of Asian Finance, Economics and Business, 4(3), 45-56. http://dx.doi.org/10.13106/jafeb.2017.vol4.no3.45

Morathop, N., Kanchanakitsakul, C., Prasartkul, P., \& Satayavongthip, B. (2010). Intention to Work in One's Hometown: Seniors at Naresuan University, Phitsanulok Province. Journal of Demography, 26(2), 1-12.

Mustapa, N. S., Noor, M. K., \& Mutalib, M. A., (2018). Why Can't We Have Both? A Discussion on Work-Life Balance and Women Career Advancement in Malaysia. Journal of Asian Finance, Economics and Business, 5(3), 103-112. http://doi. org/10.13106/jafeb.2018.vol5.no3.103

Nguyen, T. T. (2015). Determinants of Student Intention to Work in Hometown. VNU Journal of Science: Economics and Business, 31(5), 1-9.

Nguyen, H., \& McPeak, J. (2010). Leaving or Staying: InterProvincial Migration in Vietnam. Asian and Pacific Migration Journal, 19(4). 473-500.

Nguyen, T. T. H., Nguyen, T. T. H., Nguyen, T. L. H., \& Nguyen, V. C. (2020). The Impact of International Integration on the Inequality of Income between Rural and Urban Areas in Vietnam. Journal of Asian Finance, Economics and Business, 7(3), 277-287. https://doi.org/10.13106/jafeb.2020.vol7. no3.277

Niedomysl, T., \& Amcoff, J. (2010). Why return migrants return: survey evidence on motives for internal return migration in Sweden. Population, Space and Place, 17(5), 656-673. doi:10.1002/psp.644.
Nota, L., Ferrari, L., Solberg, V., \& Soresi, S. (2007). Career Search Self-Efficacy, Family Support, and Career Indecision With Italian Youth. Journal of Career Assessment, 15(2), 181-193. doi:10.1177/1069072706298019.

Pearson, L., \& Andres, C. (2010). Job Location Decisions of Pharmacy Graduates in British Columbia. American Journal of Pharmaceutical Education, 74(4), 74- 89.

Rérat, P. (2014). The Selective Migration of Young Graduates: Which of Them Return to Their Rural Home Region and Which Do Not. Journal of Rural Studies, 35(1), 123-132.

Soon, J. J. (2010). The Determinants of Students' Return Intentions: A Partial Proportional Odds Model. Journal of Choice Modelling, 3(2), 89-112. https://doi.org/10.1016/S17555345(13)70037-X.

Todaro, T. (1969). A Model of Labor Migration and Urban Unemployment in Less Developed Countries. The American Economic Review, 59(1), 138- 154.

Wang, W., \& Fan, C. (2006). Success or Failure: Selectivity and Reasons of Return Migration in Sichuan and Anhui, China. Environment and Planning A: Economy and Space, 939-958. https://doi.org/10.1068/a37428.

Williams, D., \& Vaske, J. (2003). The Measurement of Place Attachment: Validity and Generalizability of a Psychometric Approach. Forest Science, 49(6).

Yigitcanlar, T., Baum, S., \& Horton, S. (2007). Attracting and Retaining Knowledge Workers in Knowledge Cities. Journal of Knowledge Management, 11(2), 6-17. DOI: 10.1108/13673270710819762.

Yue, Z., Li, S., Feldman, M. W., \& Du, Z. (2010). Floating Choices: A Generational Perspective on Intentions of Rural-Urban Migrants in China. Environment Plan A, 42(3), 545-562. 
